\title{
UPACARA MANENUNG MENURUT AGAMA HINDU KAHARINGAN DI DESA PETAK BAHANDANG KECAMATAN KURUN KABUPATEN GUNUNG MAS
}

\author{
Hendri \\ Institut Agama Hindu Negeri Tampung Penyang Palangkaraya \\ bawiayahfda@gmail.com
}

\section{Riwayat Jurnal (Style Bawi Ayah_Riwayat)}

Artikel diterima

$:-$

Artikel direvisi

$:-$

Artikel disetujui

\begin{abstract}
Abstrak
Emosi keagamaan yang menyebabkan manusia mempunyai sikap dan perilaku yang serba religius merupakan suatu getaran yang menggerakkan jiwa manusia. Sistem keyakinan dalam suatu religius terwujud pikiran, moralitas dan gagasan manusia yang menyangkut keyakinan. Sistem ritus dan upacara dalam religi terwujud tindakan manusia dalam melaksanakan kebaktiannya terhadap Tuhan, Dewa-Dewi Nenek Moyang atau makhluk lainnya. Dalam sistem ritus dan upacaranya biasanya digunakan sasaran dan peralatan upacara. Upacara ritual merupakan bentuk dari kebudayaan yang telah mengalami perkembangan dan beradaptasi, tetapi tidak mempengaruhi makna dan tujuan yang merupakan local genius atau kebudayaan setempat. Upacara ritual yang dilakukan dengan harapan apa yang menjadi keinginan dapat tercapai. Upacara Manenung yaitu melalui beberapa tahapan, yaitu (1) Tahap pertama diawali dengan mendatangi Basir atau rohaniawan pelaksana upacara ritual Manenung dan dengan membawa berbagai alat yang digunakan dalam proses upacara ritual tersebut. Ritual tersebut mengandung nilai pendidikan agama Hindu yaitu Tattwa, Susila, dan Upacara.

Kendala yang dihadapi dalam menanamkan Nilai Pendidikan Agama Hindu dalam Upacara Manenung menurut Umat Hindu Kaharingan di Desa Petak Bahandang Kecamatan Kurun Kabupaten Gunung Mas yakni : (a) Adanya anggapan dari luar atau non Hindu bahwa Bahwa upacara-upacara ritual yang dilakukan sebagai adat budaya sehingga upacara Manenung dikatakan sebagai adat budaya.
\end{abstract}

Kata Kunci : Upacara, Manenung dan Hindu Kaharingan

\section{Pendahuluan}

Suku Dayak sangatlah peka dengan sebuah mitos, karena mitoslah yang menjadi sumber rujukan meraka selama ini, mulai dari nenek moyang meraka hingga sekarang, mitos adalah sebuah cerita yang menceritakan cerita masa silam yang berkaitan dengan 
keyakinan dan kekuatan spiritual. Dalam mitos ada terdapat sebuah keyakinan tentang roh-roh yang berada di alam sebelah yang bisa dimintai pertolongan dengan persyaratan-persayaratan yang sangat mudah didapat bagi suku mereka, yaitu dalam sebuah upacara yang mereka namakan dengan upacara Manenung, apa sebenarnya arti dari Manenung dan dari mana asal-usul Manenung dan bagaimana persyaratan-persyaratan yang harus dilakukan ketika hendak memulai ritual tersebut dan bagaimana tentang pantangannya.

Agama Hindu Kaharingan dalam pelaksanaan ajarannya menganut sistem Ekae (Tempat), Katika (Waktu) dan Hampea (kapan) atau dalam ajaran Agama Hindu dikenal dengan istilah Desa, Kala dan Patra yang berpegang pada 3 (tiga) kerangka Dasar Agama Hindu, sehingga dapat mempertahankan upacara-upacara keagamaan yang sesuai dengan budaya dan adat istiadat setempat hal ini membuat adanya perbedaanperbedaan jenis dan upacara antara satu daerah dengan daerah lainya, namun mempunyai hakekat dan nilai-nilai yang sama (Pendit, 1993:23).
Upacara Manenung ini makin langka dilaksanakan, karena pemahaman masyarakat Hindu Kaharingan terhadap ritual tersebut sangat kurang. Keadaan demikian perlu mendapat perhatian oleh lembaga Agama Hindu Kaharingan, karena upacara ritual Manenung mengandung nilai yang sangat tinggi dan sangat bermanfaat dalam kehidupan masyarakat pada umumnya dan masyarakat Hindu Kaharingan pada kususnya.

Berdasarkan latar belakang tersebut diatas, penulis tertarik untuk melaksanakan penelitian dengan judul "Upacara Manenung Pada Masyarakat Hindu Kaharingan Didesa petak Bahandang Kecamatan Kurun Kabupaten Gunung Mas.

\section{Pembahasan}

\subsection{Pelaksanaan Upacara Manenung}

Upacara "Manenung" umat Hindu Kaharingan di Desa Petak Bahandang merupakan satu dari lima macam upacara ritual besar di Kalimantan Tengah. Manenung adalah merupakan suatu upacara untuk memohon petunjuk kepada Sahur Parapah yang mampu menyertai dan melindungi. Upacara Manenung dilaksanakan disetiap siklus hidup umat 
Hindu Kaharingan mulai dalam Kaharingan mengetahui tata cara kandungan, lahir, tumbuh dewasa, pelaksanaan dari setiap upacara-upacara menikah, sakit hingga meninggal. ritual tersebut.

Sebagai contoh Manenung untuk anak Upacara Manenung merupakan semasih dalam kandungan ibunya sampai bayi lahir, tumbuh dan hidup sehat. Upacara Manenung menggunakan Tawur untuk menyampaikan segala kehendak, harapan dan mohon petunjuk kepada Ida Sang Hyang Widhi Wasa/Ranying Hatalla Langit. Dengan demikian, Manenung berarti merupakan suatu upacara untuk memohon petunjuk kepada Sahur Parapah yang mampu menyertai dan melindungi, dengan melaksanakan proses ritual Manenung atau mohon Petunjuk menanyakan terhadap Bawi Putir Santang/manifestasi Ranying Hatalla.

Hindu Kaharingan merupakan agama mayoritas yang dianut penduduk Desa Petak Bahandang. Hal tersebut dapat menjadi potensi yang baik guna pengembangan ajaran Hindu Kaharingan di Desa Petak Bahandang seperti dalam upacara-upacara ritual. Walaupun dalam jumlah mayoritas, belum tentu sistem nilai yang di dalamnya masih dipegang sebagai acuan kehidupan bersama dalam masyarakatnya dan semua umat Hindu setiap upacara, tetapi tujuan pada upacara-upacara ritual yang memang khusus sesuai dengan tujuan dari upacaraupacara ritual tersebut. Upacara Manenung dilaksanakan apabila di dalam Upacara Ritual tersebut harus berkaitan atau berhubungan dengan Memohon Manifestasi Tuhan Sahur Parapah. Upacara Ritual Manenung ini bertujuan yaitu memohon petunjuk dengan Ranying Hatalla Langit melalui ManifestasiNya atau Sahur Parapah Baratuyang Hawun.

Upacara Manenung merupakan rangkaian upacara yang dilaksanakan berbeda-beda dalam beberapa upacara Upacara Manenung memerlukan beberapa sarana seperti yang diuraikan dalam hasil wawancara sebagai berikut :

1. Amak Pasar eka munduk Manawur

2. Mangkuk Tawur nyung behas campur kikis Mas Perak

3. Tambak lengkap simpa ruku behas hambaruan dan kambang

4. Kasan Undus Garu Manyan dan Parapen eka barah apui 
5. Baliung, Pisau, Mandau, Bisak Tenggang (Sipet, Pisih)

6. Bandera imasang intu baun huma.

Adapun susunan tata cara pelaksanaan upacara manenung adalah sebagai berikut :

1. Tahap pertama diawali dengan mendatangi para Basir atau rohaniawan pelaksanaan upacara ritual dan dengan sebagai alat yang digunakan dalam proses upacara ritual tersebut, proses pemotongan hewan kurban, ritual Manenung dengan rangkaian diantaranya Manawur, Nantilang Liau yang disebut sebagai ritual untuk menjauhkan roh jahat dari para basir tersebut.

2. Tahap kedua pelaksanaan Upacara Manenung dengan tujuan mengundang para leluhur, selanjutnya para roh leluhur dipersilahkan untuk menerima makanan atau sesajen yang telah dipersiapkan, setelah itu baru dilanjutkan dengan Manenung.

Selain sebagai sarana untuk menyampaikan permohonan pada Sang Kuasa, Manenung juga dimaksudkan sebagai wadah untuk menjalin semangat persaudaraan dan kegotong-royongan antar sesama warga dan pemeluk agama.
Manenung merupakan proses tahapan kegiatan upacara dalam ritual yang memiliki tujuan sesuai dengan jenis upacara yang dilaksanakan atau dikhususkan pemujaan terhadap Dewa (Sahur Baragantung Langit Tundun Parapah Baratuyang Hawun). Dalam pelaksanaanya Basir/Pisor duduk Manawur Manarinjet Kajalahan Bawin Tawur supaya menerima persembahan sesajen yang sudah disediakan, setelah itu Manawur sambil menunggu Sahur Parapah sudah menerima persembahan atau makan, dan dilanjutkan dengan Manenung, dengan menyedikan sarana seperti gang, pakaian, Mandau, Kain merah putih, kuning. Tampung Tawar dan duit sebagai Katekang Hambaruan Dengan demikian pelaksanaan Manenung harus melalui beberapa tahapan seperti melakukan Manawur Manarinjet Kajalahan Sahur sampai tahapan terakhir dan tidak lepas dari sarana dan prasarana yang digunakan untuk dipersembahkan terhadap manifestasi Tuhan/Ranying Hatalla Langit. 


\subsection{Nilai Pendidikan Agama Hindu dalam Upacara Manenung menurut Umat Hindu Kaharingan di Desa Petak Bahandang}

\subsubsection{Nilai Tattwa}

Tattwa atau disebut dengan filsafat atau falsafah, yang merupakan bagian dari aspek ajaran agama Hindu yang sangat mendominasi disegala sisi kehidupan. Karena hampir semua sisi kehidupan selalu mengandung makna falsafah. Seperti contoh bagi umat Hindu Kaharingan mempersembahkan sesaji kepada manifestasi-manifestasi Ranying Hatalla Langit (Tuhan Yang Maha Agung) merupakan falsafah yang mengandung arti bahwa persembahan yang dilakukan merupakan tanda syukur dan terima kasih atas karunia yang diberikan yang diwujudkan dengan sebuah sesaji. Keyakinan atau kepercayaan disebut sradha, sradha ada lima macam yang disebut panca sradha.

Dari Panca Sradha tersebut terkandung nilai pendidikan agama Hindu dalam Upacara Manenung, keterkaitannya yaitu Upacara Manenung merupakan suatu sistem religi dengan suatu keyakinan terhadap Tuhan Yang Maha Esa. Hal ini juga terlihat dalam agama Hindu Kaharingan yang tergolong dalam lima kepercayaan/keyakinan (Lime Sarahan), dan bagian-bagianya yaitu:

1. Ranying Hatalla Katamparan

2. Langit Katambuan

3. Petak Tapajakan

4. Nyalung Kapanduian

5. Kalata Kapadadukan

Dari Lime Sarahan tersebut merupakan suatu sistem religi dengan suatu keyakinan terhadap Tuhan Yang Maha Esa. Kemahakuasaan Tuhan dalam pandangan agama Hindu Kaharingan digambarkan sebagai wujud atau perwujudan yang paling tinggi dan memenuhi seluruh alam semesta.

Tattwa dalam mengkaji ranah kognitif yaitu kepercayaan dan keyakinan umat Hindu Kaharingan di Desa Petak Bahandang yang mendalam terhadap keberadaan Tuhan beserta manifestasiNya (Widhi Sradha), menjadi landasan konseptual bagi umat Hindu Kaharingan untuk melaksanakan Yadnya sebagai perwujudan cetusan rasa bhakti umat manusia kepada Ranying Hatalla Langit atau Ida Sang Hyang Widhi Wasal/Tuhan Yang Maha Esa. Hal ini adalah usaha mencari perlindungan kepada Tuhan yang telah menciptakan segala isi alam, karena segala yang ada bersumber dari-Nya, Tuhan telah menciptakan segala isi alam 
dengan jalan yadnya, maka manusia melakukan usaha mencari perlindungan dengan yadnya pula.

Tattwa artinya kebenaran, kebenaran yang mencakup hakekat Tuhan dalam alam semesta. Tattwa digunakan untuk menyatakan kebenaran itu. Cara memandang kebenaran itu berbeda-beda, perbedaan pandangan itulah yang menyebabkan adanya pengetahuan tentang tattwa berbeda-beda pula. Dalam buku Etika Hindu dan Perilaku Organisasi bahwa "tattwa merupakan uraian filosofi tentang ajaran-ajaran yang tersimpul dalam Panca Sradha" (Gorda, 1996:30).

Berdasarkan uraian di atas, dapat diungkapkan bahwa unsur pendidikan tattwa (filsafat) dalam upacara Agama Hindu menyangkut tentang ajaran Panca Sradha. Tetapi tidak semua pembagian dari Panca Sradha yang dapat dihubungkan dengan nilai pendidikan tattwa dalam Manenng. Hubungannya dengan Manenung adalah salah satu bentuk sarana persembahan kepada Ranying Hatalla Langit/Ida Sang Hyang Widhi Wasa beserta manifestasi-Nya sebagai pelengkap di Desa Petak bahandang. Manenung merupakan bagian dari Upacara Manenung yang merupakan suatu wujud keyakinan warga masyarakat kepada Ranying Hatalla Langit/Ida Sang Hyang Widhi Wasa untuk mendapatkan keselamatan dan kerahayuan.

Adapun yang melatar belakangi pelaksanaan ritual Manenung dalam kehidupan umat Hindu Kaharingan adalah keyakinan bahwa Raja Bunu dan keturunannya adalah manusia yang tidak kekal dan akan mendiami kehidupan semesta di Pantai Danum Kalunen atau dunia. Namun, disampaikan Ranying Hatalla dalam Panaturan pasal 29 ayat 5:

" Tinai kuan Ranying Hatalla, ela bitim ngupang basule huang bahing pahariwut rawei-Ku, tarantang aim dia memen bewei, aluh ewen te puna bagin matei, te kareh tege panarantang tambun paharin ije dia tau matei, ije akan haduanan ewen te kareh buli AKU",

Artinya :

Ranying Hatalla kembali menyebutkan; engkau jangan merasa khawatir dengan petunjuk dari-Ku, walaupun keturunanmu menjadi bagian yang mati, mereka itu akan dibantu oleh keturunan kedua saudaramu mengembalikannya menyatu kepada-KU.

Dalam keyakinan Kaharingan, manusia adalah anak keturunan dari Raja Bunu, pada mulanya Raja Bunu memiliki 
dua orang saudara, yaitu Raja Sangen dan Raja Sangiang. Dengan kehendak dan kekuasaan Ranying Hatalla Langit maka dikehendaki bahwa Raja Bunu kelak yang akan mendiami dunia atau Pantai Danum Kalunen yang tidak kekal ini.

"Raja Bunu tempun hila sanaman ije leteng, iete awi Ranying Hatalla ewen ndue Jatha Balawang Bulau mahaga Lewu Injam Tingang, Pantai Danum Kalunen kareh ije bagin matei."

Artinya :

Raja Bunu mendapatkan bagian besi yang tenggelam, juga telah ditetapkan oleh Ranying Hatalla dan Jatha Balawang Bulau untuk memelihara kehidupan dunia yang sifatnya hanya sementara (Panaturan, 23:23).

Namun, kedua saudara Raja Bunu tersebut pula dikehendaki Ranying Hatalla agar selalu membantu saudaranya di Pantai Danum Kalunen tersebut. Sehingga dalam segala macam upacara Hindu Kaharingan termasuk ritual Manenung selalu ada mantra dan juga prosesi penyampaian doa kepada para Sahur Parapah melalui Basir/Pisor yang menjadi perantara komunikasi manusia dengan Ranying Hatalla Langit agar dapat membantu kelancaran ritual tersebut agar dapat berjalan dengan baik.

\subsubsection{Nilai Susila}

Etika/susila merupakan bagian dari kerangka dasar Agama Hindu. Dalam etika/susila diajarkan untuk menentukan perbedaan perbuatan yang baik dan mana perbuatan yang buruk "Etika adalah bentuk pengendalian diri dalam pergaulan hidup bersama" (Sura, 2001:38). Dalam kehidupan bersama itu orang harus mengatur dirinya bertingkah laku dan menyesuaikan dirinya dengan lingkungan serta tunduk kepada aturan bertingkah laku yang berlaku.

Ahli lain mengatakan bahwa etika memuat pengetahuan tentang kesusilaan. "Kesusilaan berbentuk kaidah-kaidah yang berisikan larangan-larangan atau suruhan-suruhan untuk berbuat sesuatu. Dalam etika juga akan tercermin ajaran perbuatan yang baik dan buruk. Perbuatan yang baik itulah mesti diikuti dan perbuatan yang buruk harus dihindari" (Netra, 1994:140).

Manusia menghendaki untuk mendapatkan tujuan dari keinginannya. Kehendak berakibat dalam kegiatan yang disebut perilaku, perilaku adalah kebiasaan manusia yang berasal dari keinginan. Kadang ada pertentangan dari keinginan yang memperoleh kemenangan 
yang diistilah dengan "kehendak" dan kecenderungan batin yang membuat kehendak menjadi mungkin disebut watak ataau karakter.

Dalam Upacara Manenung, nilai pendidikan yang terdapat dalam Susila yaitu Tri Hita Karana yang merupakan penyebab keharmonisan dalam kehidupan di dunia. Adapun ciri dari Tri Hita Karana pada Upacara Manenung tersebut yaitu :

a. Hubungan manusia dengaan Tuhan, dalam upacara tersebut hubungan manusia dengan Tuhan terlihat pada tujuannya yaitu memohon kepada Tuhan agar diberikan kebahagiaan, keselamatan, dan kesejahteraan dalam menjalani kehidupan

b. Hubungan manusia dengan alam dalam upacara Manenung hubungan manusia dengan alam terlihat pada sarana atau sesaji yang selalu memanfaatkan dari alam. Ini karena segala sesuatu yang ada berasal dari alam yang mencerminkan bahwa manusia dengan alam terjalin hubungan yang harmonis.

c. Hubungan manusia dengan sesama manusia, dalam upacara Manenung hubungan manusia dengan manusia terlihat dari bentuk upacaranya, dimana interaksi dari para anggota upacara ritual bersama-sama menjaga jalannya upacara tersebut sehingga berjalan dengan lancar dan harmonis.

\subsubsection{Nilai Upacara}

Bagi manusia sudah merupakan suatu kewajiban untuk menghormati segala sesuatu yang telah diciptakannya dengan cara melaksanakan upacara yadnya untuk keseimbangan alam semesta. Cetusan rasa hormat dapat dilaksanakan dengan berbhakti pada Beliau. Dalam mewujudkan rasa bhakti, rasa kasihnya kehadapan Tuhan yang telah menciptakan alam semesta beserta isinya. Terkait upacara Manenung, nilai pendidikan dalam upacara dapat dilihat dari pelaksanaan Manenung tersebut yang tidak terlepas dari kegiatan keagamaan di Desa Petak Bahandang. Rangkaian kegiatan keagamaan dilengkapi dengan sarana upakarta, baik berupa Sumpit, Mandau, Beliung dan Pisih, ataupun alatalat lain yang digunakan sebagai penunjang upacara. Dalam melengkapi atau menyediakan sarana yang digunakan pada upacara ritual tersebut, umat Hindu Kaharingan bersama masyarakat di Desa Petak Bahandang melakukan aktivitas 
dalam menyediakan sesajen membuat ketupat, lemang dan sarana lainnya serta membersihkan lokasi atau tempat dilaksanakan upacara tersebut.

Pelaksanaan upacara Manenung merupakan salah satu rangkaian dari upacara keselamatan. Dalam pelaksanaan upacara ini memerlukan sarana atau sesaji sebagai bentuk korban suci yang wajib dilakukan. Kalau ditinjau secara etimologinya, kata yadnya berasal dari Bahasa Sanskerta, yaitu dari kata " yaj” yang artinya memuja atau memberi penghormatan, mempersembahkan, dan bertindak sebagai perantara, dari urat kata ini timbul kata "yajna" yang artinya pemujaan, doa, persembahan. Jadi yadnya dapat juga diartikan yaitu korban suci yang didasarkan atas pengabdian dan cinta kasih. Pertimbangan dalam pelaksanaan upacara yadnya yang menyangkut desa, kala, patra untuk masyarakat umum biasa disebut dengan local genius.

Berdasarkan uraian tersebut, dapat penulis simpulkan bahwa nilai pendidikan yang terkandung dalam Upacara Manenung di Desa Petak Bahandang dalam mengkaji ranah psikomotorik/gerakan, nilai, pendidikan yang terkandung dalam upacara yaitu dilihat dari berbagai bentuk seni kesakralan seperti yang terdapat dalam upacara Manenung di Desa Petak Bahandang yaitu dapat dilihat, sehingga nilai keindahan dalam pembuatan sarana tersebut tergolong dalam bentuk seni rupa. Selain itu penulis menambahkan bahwa dalam pelaksanaan Manenung di Desa Petak Bahandang terdapat nilai seni suara. Seni suara yang dimaksud yaitu disaat lantunan tandak Manawur berlangsung memberikan ekspresi religius sebagai media komunikasi.

\subsection{Kendala yang dihadapi dalam Menanamkan Nilai Pendidikan Agama Hindu dalam Upacara Manenung Menurut Umat Hindu Kaharingan di Desa Petak Bahandang}

Pendidikan karakter harus berkelanjutan dan tak pernah berakhir, sebagai bagian terpaduuntuk menyiapkan generasi bangsa, yang yang disesuaikan dengn sosok manusia masa depan berakar pada filosofi dan nilai kultur religious bangsa Indonesia. Pendidikan karakter harus menumbuhkembangkan filosofi dan pengamalan atas keseluruhan karakter bangsa ini secara utuh dan menyeluruh. Karakter bangsa mengandung perekat 
budaya dan kultur yang harus terwujud dalam kesadaran kultul dan kecerdasan kultul pada setiap warga negara. Pendidikan karakter memiliki makna lebih tinggi dari pada pendidikan moral, karena pendidikan karakter tidak hanya berkaitan dengan masalah benar dan salah, tetapi bagaimana menanamkan pembiasaan dengan hal-hal yang baik dalam kehidupan, sehingga peserta didik memiliki kesadaran, kepekaan, dan pemahaman yang tinggi. Serta kepedulian dan komitmen untuk menerapkan kebajikan dalam tindakan nyata melalui prilaku yang baik, jujur, ikhlas, bertanggung jawab hormat terhadap orang tua, dan nilai-nilai karakter mulia yang lainnya dalam kehidupan seharihari. Dengan demikian orang yang berkarakter merupakan sifat yang alami seseorang dalam merespon situasi secara bermoral yang diwujudkan. Pendidikan adalah proses seseorang dalam rangka mengembangkan kemampuannya, sikap, dan tingkah laku di dalam masyarakat tempat mereka berada. Pendidikan adalah proses sosial yang terjadi pada orang yang dihadapkan pada pengaruh lingkungan yang terpilih dan terkontrol (khususnya yang datang dari pendidikan formal), sehingga mereka dapat memperoleh perkembangan kemampuan sosial dan kemampuan individu yang oftimal, pendidikan dipengaruhi oleh lingkungan atas individu untuk menghasilkan perubahan-perubahan yang sifatnya permanen (tetap) dalam tingkah laku, pikiran, dan sikapnya. Pendidikan juga diartikan dalam bahasa agama disebut dengan Widya yang merupakan catatan dari kebijaksanaan, yang di dalamnya mengandung tentang kebenaran tertinggi. Weda mengajarkan tentang bagaimana cara untuk mencapai kemurnian hati. Pendidikan juga usaha untuk membangkitkan kecerdasan dan mempertajam kemampuan untuk membedakan yang baik dan buruk, benar dan salah (Singer, 2002:25). Pendidikan itu untuk menanamkan kebiasaankebiasaan yang diinginkan oleh pendidikan itu sendiri yang pada akhirnya menjadi kebiasaan hidup dan tumbuh bekembang menjadi karakter atau kepribadian yang sulit untuk dirubah lagi. Jadi pendidikan atau lingkungan sangat berpengaruh dengan pembentukan karakter.

Dalam Nitisatra disebutkan : 
nora na mitramang lwihane, wara guna maruhur, nora'na catru manglewihane, geleng ana ri hati, nora 'na sih mahanglewihane, sihikang atanaya, nor'na cacti daiwa juga sakti, tan ana mamahen artinya:

Tidak ada sahabat yang melebihi pengetahuan, yang mempunyai manfaat atau berfaedah sangat tinggi bagi kehidupan, tidak ada musuh yang berbahaya dari nafsu jahat yang tumbuh dalam hati, tidak ada cinta yang melebihi cinta orang tua kepada anak-anaknya, merupakan sarana pendidikan yang efektif, tidak ada menyamai kekuatan kecuali nasib, karena kekuatan nasib tidak tertahan oleh siapapun (Singer, 2017:28).

Dengan menyimak sloka di atas bahwa peranan pendidikan itu dalam rangka mewujudkan anak didik yang berkarakter atau berkepribadian yang sangat kuat, tidak mudah dipengaruhi oleh hal-hal yang bersifat material. Karakter mulia yang melandasinya sifatsifat seseorang akan tercermin dalam tingkah laku sehari-hari. Tingkah laku tersebut akan terlihat dan dapat diamati dari tiga hal seperti sabda, bayu dan idep. Idep terimplementasi dalam pikiran merupakan sumber dari bentuk-bentuk pikiran itu sendiri yang diikuti oleh ucapan-ucapan, kata-kata dan perbuatan. Untuk menyeimbangkan pikiran, perkataan dan perbuatan kita maka kita harus mawas diri, introspeksi diri, mulat sarira yang bertujuan untuk memperoleh kedamaian. Karena kedamaian adalah dambaan bagi semua orang, kedamaian kebahagiaan utama, kebahagiaan tanpa kedamaian tidak akan ada. Karakter manusia sangatlah besar. Kedamaian dapat dicapai tergantung dari karakter kecakapan hati dan pandangan hidup atau pemikiran manusia itu sendiri. Ajaran Tri Kaya Parisudha sebagai landasan pembentukan karakter yang sangat dominan sebab salah satu tata nilai yang merupakan tata susila Hindu. Tri Kaya Parisudha yang cukup penting dalam implementasinya dalam seluruh kehidupan masyarakat, agar tercapainya keharmonisan dalam kehidupan masyarakat, untuk tercapainya keberhasilan pendidikan dan penanaman konsep pembentukan pendidikan karakter, yang diperlukan sistem kedisiplinan yang tinggi.

Pendidikan karakter adalah proses internalisasi budaya ke dalam diri seseorang dan masyarakat sehingga membuat orang beradab. Pendidikan bukan saja sebagai sarana transper ilmu pengetahuan, lebih luas sebagai sarana 
pembudayaan dan penyaluran nilai (enkulturisasi dan sosialisasi). Anak didik agar mendapatkan pendidikan yang menyentuh dimensi dasar kemanusiaan. Dimensi kemanusiaan mencakup tiga hal yaitu (1) Afektif yang tercermin dalam kualitas keimanan, ketakwaan, akhlak mulia, termasuk budhi pekerti, yang luhur, serta kepribadian yang unggul, dan kompensi estetis. (2) Kognitif yang tercermin dalam kapasitas pikir dan daya intlektualitas untuk menggali dan mengembangkan serta menguasai ilmu pengetahuan dan teknologi.

Psikomotorik yang tercermin dalam kemampuan mengembangkan ketrampilan teknis, kecakapan praktis, dan kompetensi kinestetis. Pendidikan karakter menjadi bagian yang paling berharga di dalam kehidupan manusia.aspek utama pendidikan karakter merujuk pada kualitas instinsik seperti kejujuran, kebaikan hati, ketenangan, kesetiaan, industri dalam artian bentuk kerja keras, aktif dan integitas (Julian dan Jhon, 2008:115). Pendidikan karakter adalah suatu sistem pemahaman nilainilai pendidikan karakter kepada anak didik yang meliputi komponen pengetahuan, kesadaran, atau kemauan dan tindakan untuk melaksanakan nilainilai tersebut. Akhirnya penulis berharap semoga tulisan ini dapat memberikan sumbangan pemikiran wawasan dan pmahaman para pembaca yang budiman dalam rangka membangun karater bangsa dan membantu para pendidik dalam melaksanakan pendidikan karakter secara tepat dan efektif.

\section{Penutup}

\subsection{Kesimpulan}

1. Pelaksanaan upacara Balian Manenung yaitu melalui beberapa tahapan, yaitu tahap pertama diawali dengan mendatangi Basir pelaksanaan upacara ritual dan Katambung sebagai alat yang digunakan dalam proses upacara ritual tersebut, menyediakan sarana ritual, dengan rangkaian diantaranya Manawur, Nantilang Liau yang disebut sebagai ritual untuk menjauhkan roh jahat dari para basir. Tahap kedua dilanjutkan dengan ritual Mangkang Sangiang, Panaturun Sangiang. Tahap ketiga dengan Balian Narinjet Sahur tujuan mengundang para leluhur, dan dengan menyediakan sarana seperti, pakaian, Mandau, kain merah/putih/kuning. Tampung Tawar 
dan duit sebagai Katekang

\section{Hambaruan.}

2. Nilai Pendidikan Agama Hindu dalam Upacara Manenung menurut Umat Hindu Kaharingan Di Desa Petak Bahandang yaitu Tattwa, Susila, dan Upacara .

3. Kendala yang dihadapi dalam menanamkan Nilai Pendidikan Agama Kaharingan di Desa Petak Bahandang Kaharingan di Desa Petak Bahandang Kecamatan Kurun Kabupaten Gunung Mas, yakni : a. Disebabkan karena perkembangan jaman menyebabkan kemajuan teknologi sehingga kesadaran generasi muda umat Hindu Kaharingan Desa Petak Bahandang semakin meninggalkan ajaran tentang bagaimana melestarikan kegiatan ritual agama seperti dalam melaksanakan upacara Manenung. b). Upaya dalam melakukan pembinaan atau pengajaran terhadap generasi muda umat Hindu Kaharingan di Desa Petak Bahandang tentang pembuatan sarana ritual sudah tidak efektif lagi. c) Kurangnya perhatian atau bimbingan dari orang tua maupun dari majelis terhadap generasi muda sehingga berpengaruh terhadap aktivitas kebebasaan dalam mengenal budaya luar. d). Dengan perjudian dan minuman keras yang sudah membudaya. e). Adanya opini dari luar atau non Hindu bahwa upacara-upacara ritual yang dilakukan khususnya seperti upacara Manenung dikatakan sebagai cara menduakan Tuhan; f) Kurangnya penyediaan waktu untuk pemberian Pendidikan Agama Hindu dalam prosesi upacaraupacara yang dilaksanakan khususnya dalam upacara Manenung $g$ ). Kurangnya peranan guru agama dalam melakukan pengajaran pembuatan sarana ritual. h) Keaktifan pengurus MK-AHK Desa Petak Bahandang tentang tata kelola organisasi menurun. i) Kurangnya adanya interaksi dan kerjasama antara Guru Agama Hindu dengan umat tentang pengadaan bukubuku keagamaan Hindu secara umum (Weda, Tri Hita Karana, pedoman tenaga pembina, menumbuh kembangkan pendidikan budhi pekerti pada umat generasi muda/ perspektif agama Hindu dan lain-lain), serta cara dan tempat memperolehnya.

\subsection{Saran}

Sehubungan dengan Upacara Manenung yang dilaksanakan di Desa 
Petak Bahandang Kecamatan Kurun Kabupaten Gunung Mas, maka ada beberapa hal yang peneliti jadikan saran, antara lain:

1. Perlu adanya kerjasama antara pihakpihak yang berkompeten dibidang ini Hindu (Guru Agama Hindu, Basir, pengurus MK-AHK dan dukungan dari umat Hindu Kaharingan) untuk melakukan pembinaan terhadap umat Hindu Kaharingan Desa Petak Bahandang tentang ajaran agama Hindu secara umum, khususnya tentang menanamkan nilai-nilai Pendidikan Agama Hindu.

2. Upacara Manenung merupakan salah satu media ekspresi manusia dalam memenuhi emosi religiusnya dan menjaga leserasaan hubungan manusia dengan Tuhan, manusia dengan alam, manusia dengan sesama. Oleh sebab itu, hendaknya upacara ini tetap dijaga keberadaannya sebagai salah satu wujud bhakti kepada Tuhan, dan melestarikan nilai-nilai agama serta sebagai wujud yadnya.

3. Perlu melaksanakan musyawarah rutin guna menggali permasalahan umat Hindu Kaharingan Desa Petak Bahandang dan perlu dilaksanakan pembinaan tentang ajaran agama Hindu yang mengkaitkan nilai-nilai Pendidikan Agama Hindu dengan upacara-upacara ritual guna memiliki pemahaman umat Hindu Kaharingan di Desa Petak Bahandang dari penyuluh Agama Hindu Kemenag Kabupaten Gunung Mas.

4. Hendaknya dari upacara Manenung ini dapat diambil nilai-nilai positif yang dapat dipergunakan sebagai pedoman dalam kehidupan, disamping itu diharapkan dapat memahami dan mengerti nilai pendidikan Agama Hindu yang terkandung dalam sarana dan tata cara upacara-upacara tersebut, dan hendaknya pemberian Pendidikan Agama Hindu pada umat Hindu Kaharingan di Desa Petak Bahandang dapat dilakukan melalui Basarah, upacara ritual keagamaan, dan evaluasi melalui sanksi, hukuman atau nasehat terhadap pelanggaran-pelanggaran norma agama.

\section{Daftar Pustaka}

Anwar, Desi. 2002. Kamus Lengkap Bahasa Indonesia. Surabaya : Amelia.

Anonim. 2015. Panaturan. Majelis Besar Agama Hindu Kaharingan Palangka Raya. 
Basir Thian Agan. 2000. Upacara Keselamatan Hindu Kaharingan. Palangka Raya.

Tim Penyusun. 2005. Buku Tawur Palangka Raya : Kanwil Depag Propinsi Kalimantan Tengah.

Tim Penyusun. 2005. Upacara Ritual Keselamatan Hindu Kaharingan (Buku Talatah Upacara Tulak Bala). Palangka Raya : Kanwil Depag Propinsi Kalimatan Tengah.

Koentjaraningrat. 1987. Sejarah Teori Antropoogi. Jakarta : Universitas Indonesia.

Kencong. 2006. Tesis. Upakara Hindu Kaharingan (Suatu Tinjauan Bentuk, Fungsi dan Makna dalam Agama Hindu). Denpasar : UNHI

Punjatmaja. 1976. Ilmu Pengetahuan suci. Bandung.

Riwut, Nila. 2003. Maneser Panatau Tatu Hiang. Palangka Raya : Pustaka Ilmu.

Sugono, Dendi. 2008. Kamus Besar Bahasa Indonesia Pusat Bahasa. Jakarta : PT. Gramedia Pustaka Utama.

Sura, G. 1989. Pelajaran Agama Hindu Untuk SMTA Kelas 1. Bandung : Yayasan Dharma Sarathi.

Tim Penyusun. 1994. Kamus Besar Bahasa Indonesia Edisi Kedua. Jakarta : Balai Pustaka.

Tim Penyusun. 2006. Buku Pelajaran Agama Hindu Kaharingan Untuk Tingkat SMTP. Palangka Raya : Lembaga Pengembangan Tandak dan Upacara Keagamaan Umat Hindu Kaharingan.

Tim Penyusun. 2009. Panaturan. Denpasar : Widya Dharma. 